\title{
EFFECT OF GOAT LIPASE ON SENSORY PROPERTIES OF CURD
}

\author{
EFEITO DA LIPASE DE CABRA NAS PROPRIEDADES SENSORIAIS DA \\ COALHADA
}

\author{
Ali RAJABI ${ }^{1}$; Ali Mohamadi SANI ${ }^{1}$ \\ 1. Young Researchers and Elite Club, Quchan Branch, Islamic Azad University, Quchan, Iran
}

\begin{abstract}
Curd is one the main dairy products in Iran with high nutritional value. People tend to consume traditional products with special taste and odour and this has led industrial manufacturers to use some additives to adopt the sensory properties similar to traditional ones. Animal lipase is a good choice with three sources including calve, lamb and kid ones which create perfect taste and aroma. The aim of this study was to evaluate the effect of kid goat lipase at 5 levels $(0,50,100,150,200 \mathrm{ppm})$ on some physic-chemical and sensory properties of curd in batch system. Results showed that addition of enzyme improved sensory properties and the highest score was gained in treatment containing $150 \mathrm{ppm}$ of lipase.
\end{abstract}

KEYWORDS: Lipase. Kid goat. Curd.

\section{INTRODUCTION}

Dairy products are highly regarded in recent years for both consumers (in terms of health and prevention of diseases) and manufacturers (in terms of added value to milk) (BYLUND, 2001). Curd is a dairy product manufactured by boiling and drying of Dough (a by-product of butter making) (ANONYMOUS, 2015; ANONYMOUS, 2001) Curd is a nutritive product containing high amount of calcium, protein and vitamins, therefore has a special place in Iranians diet (RAMAZANI, 1985). By the development of technology, traditional products such as Curd are produced by industrial techniques but people like traditional aroma and taste, hence manufacturers attempt to produce the traditional flavor (KARABULUT, et al., 2007. QORBAN SHIROUDI, 2009).

Lipase as a lipolytic enzyme has been used in dairy products to improve sensory properties (GORJAN, et al,. 2014). This enzyme is available in three animal's calves, lambs and kids and has been used in cheese ripening and production of enzyme modified cheeses. Lipase is widely used in the production of cow milk cheeses with taste similar to goat's or sheep's milk (SAXENA, et al., 1999). Therefore, this study investigated the effect of goat lipase on sensory properties of pasteurized curd produced by industrial method.

\section{MATERIAL AND METHODS}

Goat's lipase and starter culture YBC/1 was obtained from Micromilk (Italy). Curd was produced using different concentration of enzyme $(0,100,150,200,500 \mathrm{ppm})$. For this purpose, at first enzyme was dissolved in cold water and then simultaneously with the starter added to milk at $43^{\circ} \mathrm{C}$ and incubated for $16-18$ hours to reach the acidity about 300 dornic. Boiling the mixture lead enzyme inactivation (ANONYMOUS, 2015).

\section{pH measurement}

$\mathrm{pH}$ measured by $\mathrm{pH}$ meter (HANA model, Portugal) (ANONYMOUS ,2005).

Texture analysis

A TPA texture analyser (CNS Farnell, Hertfordshire, UK) was used to measure the force required for penetration of a round-bottom $(3.5 \mathrm{~cm}$ diameter) probe at a velocity of $60 \mathrm{~mm} / \mathrm{min}$ and descended $30 \mathrm{~mm}$ and Trigger value $0.5 \mathrm{~N}$ (KEALY, et al., 2006. SHAHIDI, et al., 2012)

\section{Sensory properties}

The sensory evaluation of the curd was done by 10 trained panellists using a hedonic scale of five points for overall acceptability (SHAHIDI, et al., 2012)

\section{Statistical Analysis}

Data were statistically analyzed by Duncan test using SPPS software version 17. A p-value of less than 0.05 was considered significant.

\section{RESULTS AND DISCUSSION}

\section{pH value}

$\mathrm{pH}$ is one the most important parameters in dairy products and national standards emphasizes $\mathrm{pH}$ to be in the specified ranges. $\mathrm{pH}$ measurement showed all samples were at acceptable limits. As can be seen in Figure 1, pH reduced by increasing the concentrations of lipase. 


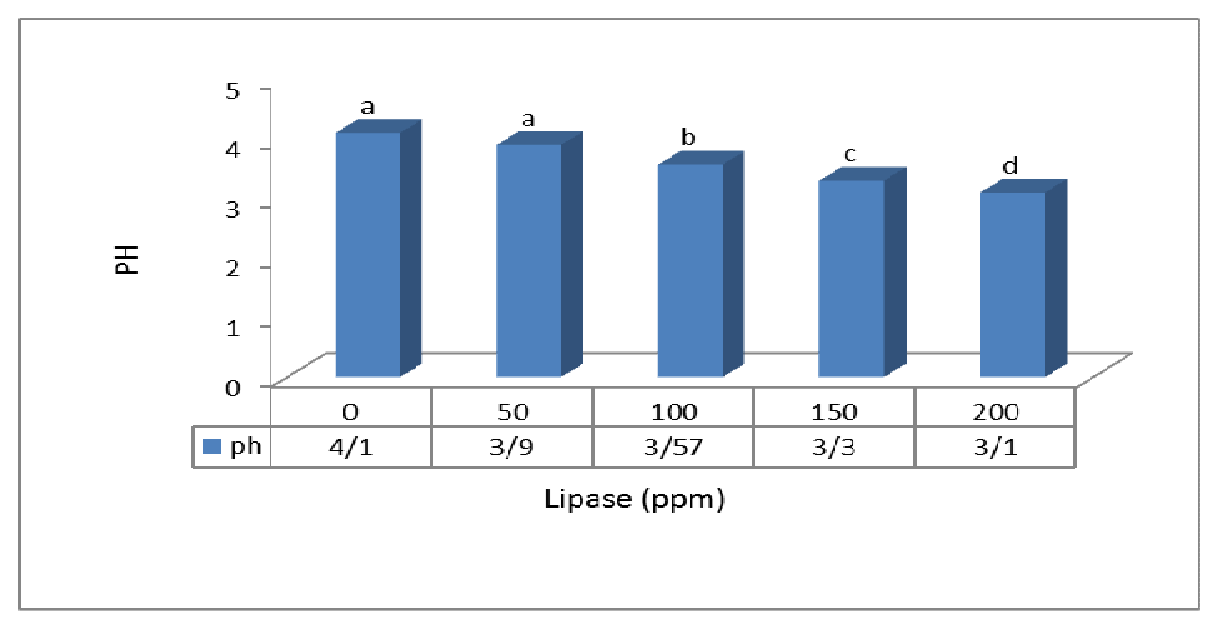

Figure1. $\mathrm{pH}$ of curd with different concentrations of lipase

\section{Texture of curd}

Using lipase in curd production, increased softness and increasing the enzyme concentration, led the curd texture to become softer. Curd containing $200 \mathrm{ppm}$ lipase had the softest texture and the control sample was the hardest one.
Lipase affected on reducing firmness through hydrolysis of di- and triglycerides to monoglycerides, which due to the emulsifying properties softened the texture (Figure 2).

Figure 2. The softness of curd with different concentrations of lipase

\section{Sensory properties}

Effect of lipase on the sensory properties is shown in Table 1 which indicates that using lipase increases the acceptance of curd by consumer. The texture score of the samples significantly increased at lipase concentrations of 100 and $150 \mathrm{ppm}$. This is fully matched with the results obtained from the texture analayser test. The color score increased by increasing the concentration of lipase up to 150 ppm, but at $200 \mathrm{ppm}$, decreased significantly $(p<0.05)$. This has been because of bleaching effect of lipase on the curd which is not favorable for consumers. Addition of enzyme increased the score of taste and aroma in comparison to the control sample. The highest score obtained at 150 and 200 ppm lipase without significant difference $(\mathrm{P}<0.05)$. Lipase improves the taste and color thought hydrolysis of fat and production of aroma and flavor (ASTON; CREAMER 1986) Researches suggested that lipase enzymes can act as flavor enhancers in dairy product (ASTON; CREAMER 1986), (DYTE 2006). The result of total acceptance test showed 
sample containing $150 \mathrm{ppm}$ lipase gained the maximum score. Application of lipase in the formulation of curd improved sensory properties and thus developed overall acceptance of the final product. Today, people tend to consumption of traditional products and believe that it is difficult for the industries to produce the product with traditional taste and aroma. Therefore industrial manufacturers should try to products with the same flavor, color and characteristics of traditional ones.

Table 1. Effect of lipase on sensory properties of curd

\begin{tabular}{llllll}
$\begin{array}{c}\text { Lipase } \\
(\mathrm{ppm})\end{array}$ & taste & Aroma & Color & texture & $\begin{array}{l}\text { Overall } \\
\text { acceptance }\end{array}$ \\
\hline control & $3.5^{\mathrm{d}}$ & $3.5^{\mathrm{d}}$ & $3.3^{\mathrm{e}}$ & $3.5^{\mathrm{e}}$ & $3.3^{\mathrm{e}}$ \\
50 & $3.8^{\mathrm{c}}$ & $3.7^{\mathrm{c}}$ & $3.8^{\mathrm{d}}$ & $3.8^{\mathrm{d}}$ & $3.6^{\mathrm{d}}$ \\
100 & $4.2^{\mathrm{b}}$ & $4^{\mathrm{b}}$ & $4.2^{\mathrm{b}}$ & $4^{\mathrm{c}}$ & $4^{\mathrm{c}}$ \\
150 & $4.4^{\mathrm{a}}$ & $4.5^{\mathrm{a}}$ & $4.4^{\mathrm{a}}$ & $4.5^{\mathrm{a}}$ & $4.5^{\mathrm{a}}$ \\
200 & $4.5^{\mathrm{a}}$ & $4.6^{\mathrm{a}}$ & $4^{\mathrm{c}}$ & $4.3^{\mathrm{b}}$ & $4.2^{\mathrm{b}}$ \\
\hline
\end{tabular}

\section{CONCLUSIONS}

The results showed that pasteurized liquid curd which produced with lipase had higher quality, although produced with industrial methods but had features similar to traditional curd.
Overall evaluation of the tests measured (texture analysis, $\mathrm{pH}$ and sensory properties) suggested that curd with $150 \mathrm{ppm}$ lipase had the best quality and maximum acceptance.

RESUMO: a coalhada é um dos principais produtos lácteos no Irã com alto valor nutricional. As pessoas tendem a consumir produtos tradicionais com gosto e odor especiais e isso levou os fabricantes industriais a usar alguns aditivos para adotar as propriedades sensoriais semelhantes às tradicionais. A lipase animal é uma boa escolha com três fontes, incluindo bezerro, cordeiro e cabrito que criam sabor e aroma perfeitos. O objetivo deste estudo foi avaliar o efeito da lipase de cabrito em 5 níveis $(0,50,100,150,200$ ppm) em algumas propriedades físico-químicas e sensoriais da coalhada no sistema de lote. Os resultados mostraram que a adição de propriedades sensoriais melhoradas enzimáticas e a maior pontuação foi obtida no tratamento contendo $150 \mathrm{ppm}$ de lipase.

PALAVRAS-CHAVE: Lipase. Cabrito. Coalhada.

\section{REFERENCES}

ANONYMOUS, (2001). Iranian National Standard Organization. Dried kashk-Specification, First Edition, n. 2452.

ANONYMOUS, (2005). Iranian National Standard Organization. Milk and milk products - determination of titrable acidity and value $\mathrm{pH}$ - test method, First Edition, n. 2852.

ANONYMOUS, (2015). Iranian National Standard Organization, Industrial liquid kashk specifications and test methods, Second Edition, n. 6127.

ASTON, J. W.; CREAMER, L. K. Contribution of the components of the water-soluble fraction to the flavour of Cheddar cheese. New Zealand Journal of Dairy Science and Technology, 1986.

BYLUND, G. Dairy processing handbook. Tetra Pak Processing Systems AB. 2003.

GOLPAYEGANI, M. A. Asian Indigenous Dairy Products, Technology of Indigenous Iranian Dairy Products, Bulletin of the International Dairy Federation, p. 29-31. 2007. 
GORJIAN, A. falah Ali Motamedzadegan, Z. Naghi Zadeh, sh. Microbial lipases: Potential biocatalysts and their's industrial applications. IRANQMS01_213. 2014.

KARABULUT, I., ADNAN HAYALOGLU, A., YILDIRIM, H. Thin layer drying characteristics of kurut, a Turkish dried dairy by product. International journal of food science \& technology, n. 42, n. 9, p. 10801086. 2007. https://doi.org/10.1111/j.1365-2621.2006.01351.x

KEALY, T. Application of liquid and solid rheological technologies to the textural characterisation of semisolid foods. Food Research International, v. 39, n. 3, 265-276. 2006.

https://doi.org/10.1016/j.foodres.2005.07.016

Qorban Shiroudi, S. The comparison of two different types of Iranian gum effect on the rheological and some microbial and chemical properties of curd. M.S. thesis of Agricultural Engineering-Food science and technology, Islamic Azad University, science and research branch. 2009.

RAMAZANI, H. Preparation of of khashk, Agriculture and Natural Resources Research Organization, 25, 2327. [in Persian]. 1985.

SAXENA, R. K., GHOSH, P. K., GUPTA, R., DAVIDSON, W. S., BRADOO, S., GULATI, R. Microbial lipases: potential biocatalysts for the future industry. Current Science, v. 77, n. 1, p. 101-115. 1999.

SHAHIDI, F.; KHALILIAN, S.; MOHEBBI, M.; KHAZAEE, E.; MAGHAMI, K. H. Evaluation of the effects of starch and guar on textural parameters, color parameters and acceptance of carrot pastille. EJFPP, v. 4, n. 2, p. 15-28. 2012.

ZHANG, H., XU, X. ; NILSSON, J. ; MU, H., ADLER-NISSEN, J. ; HØY, C. E. Production of margarine fats by enzymatic interesterification with silica-granulated Thermomyces lanuginosa lipase in a large-scale study. Journal of the American Oil Chemists' Society, v. 78, n. 1, p. 57-64. 2001. https://doi.org/10.1007/s11746-001-0220-4 